Journal of Environmental Monitoring Q Restoration 5:58-72, 2008

\title{
Kidney bean (Phaseolus vulgaris L.) production on an irrigated, coarse-textured soil in response to polymer coated urea and tillage: II. Plant $\mathrm{N}$ accumulation, nitrate leaching and residual inorganic soil $\mathrm{N}$
}

\author{
Melissa L. Wilson ${ }^{1}$, John F. Moncrief ${ }^{1,2}$, and Carl J. Rosen ${ }^{1}$
}

\begin{abstract}
Kidney bean (Phaseolus vulgaris L.) production in Minnesota is inherently at risk for nitrate $\left(\mathrm{NO}_{3}\right)$ leaching since the crop is typically grown on irrigated coarse-textured soils. These soils contain a dense Bt layer, which growers feel must be broken up through deep plowing to reduce severity of root rot. This study was conducted to determine the effects of polymer coated urea (PCU, Agrium U.S. Inc. and WSPCU, Specialty Fertilizer Products) and tillage depth on water percolation, nitrate leaching, and plant nitrogen $(\mathrm{N})$ uptake. In a split plot design, deep and shallow tillage (plow depths of 47 and $29 \mathrm{~cm}$, respectively) were whole plots while $\mathrm{N}$ treatments were subplots. Three rates of emergence applied PCU were compared with equivalent rates of urea split applied at emergence and prebloom. Along with a $0 \mathrm{~N}$ control, additional treatments included one rate of each $\mathrm{N}$ source, including WSPCU, applied at planting. Differences between tillage treatments were not found except as interactions with $\mathrm{N}$ treatment. In dry years, emergence applied PCU resulted in reduced grain $\mathrm{N}$ uptake and more cumulative $\mathrm{NO}_{3}$ leaching than split applied urea. In a wet year, however, emergence applied PCU resulted in similar plant $\mathrm{N}$ uptake and significantly less $\mathrm{NO}_{3}$ leaching that split applied urea. Planting applied PCU resulted in similar plant $\mathrm{N}$ uptake and generally less $\mathrm{NO}_{3}$ leaching compared with split applied and planting urea, regardless of leaching conditions. In dry years, planting applied WSPCU resulted in similar grain $\mathrm{N}$ uptake and $\mathrm{NO}_{3}$ leaching as planting applied urea and PCU.
\end{abstract}

Keywords: kidney bean, polymer coated urea, nitrogen rate, tillage, nitrate leaching and plant nitrogen uptake.

\section{INTRODUCTION}

Minnesota is one of the top five dry bean producing states in the U.S. and is ranked first in production of dark red kidney beans (Phaseolus vulgaris L.) (NASS, 2004). Approximately 59,000 hectares of dry beans were harvested in the state in 2007 (NASS, 2007). Dry beans are typically grown in well drained soils and generally require 2.5-3.8 cm of water every 4-5 days (Egel et al., 2008), which is often supplied by irrigation during peak evapotranspiration demand. In Central
Minnesota, dry bean production occurs on irrigated coarse textured soils that have a well defined Bt horizon with increased bulk density and reduced hydraulic conductivity. This area has a past history of severe root rot (Estevez de Jensen et al., 2004), which may be aggravated by the presence of the $\mathrm{Bt}$ horizon that confines the pathogen and plant roots to the plow layer (Burke et al., 1972). It has been shown that breaking up a restrictive layer through tillage can increase yields

${ }^{1}$ Department of Soil, Water and Climate, College of Food, Agriculture and Natural Sciences, University of Minnesota, Saint Paul, MN 55101

${ }^{2}$ Corresponding Author: moncr001@umn.edu, Phone 612-625-2771

\section{Acknowledgements}

The authors wish to thank the Legislative-Citizen Commission on Minnesota Resources for providing funding for this project, as well as Don Sirucek, Michelle Johnson, Ed Dorsey and Matt McNearney for help with field operations. 
and reduce disease severity (Burke et al., 1972; Harveson et al., 2005), but this practice has not been extensively studied in Minnesota.

Current cultural practices for dry bean production in Minnesota are inherently at an increased risk for nitrate $\left(\mathrm{NO}_{3}\right)$ leaching to groundwater. Although fertilizer $\mathrm{N}$ recovery is often low for dry beans $(<50 \%)$ (Rennie and Kemp, 1983; Tsai et al., 1993; Kipe-Nolt and Giller, 1993), current recommendations on coarse-textured soils often call for split $\mathrm{N}$ fertilizer applications. This combined with additional soil $\mathrm{N}$ supplied by biological $\mathrm{N}$ fixation and unpredictable rain events increases the potential for $\mathrm{NO}_{3}$ leaching to groundwater. Breaking up the restrictive Bt layer that is often present in the coarse textured soils of bean production regions may enhance water percolation beyond the root zone and further exacerbate the $\mathrm{NO}_{3}$ leaching problem.

Controlled release fertilizers (CRF) are one option to reduce $\mathrm{NO}_{3}$ leaching. CRFs attempt to match the release of $\mathrm{N}$ to plant uptake unlike soluble $\mathrm{N}$ sources which allow most $\mathrm{N}$ to be available to the plant in a short period of time. Reports have shown that a certain type of CRF, called polymer coated urea (PCU), increased $\mathrm{N}$ uptake by the plant and reduced $\mathrm{NO}_{3}$ leaching. Zvomuya et al. (2003) reported that polymer coated urea (PCU) applied to potato significantly reduced $\mathrm{NO}_{3}$ leaching and increased potato $\mathrm{N}$ uptake over split applications of urea in Minnesota. In a pot experiment, $\mathrm{N}$ uptake of citrus rootstock seedlings was greater with PCU than urea (Dou and Alva, 1998).

Producers have been hesitant to use PCU due to high prices (Trenkel, 1997; Zvomuya and Rosen, 2001) even though results have been promising. Recent technological advances have provided a new brand of PCU to the market that is competitively priced with other $\mathrm{N}$ fertilizers. The use of this PCU, called Environmentally Smart Nitrogen (ESN, Agrium U.S. Inc), resulted in reduced $\mathrm{NO}_{3}$ leaching in potato compared with untreated $\mathrm{N}$ sources (Wilson, 2008). The effect of PCU on $\mathrm{NO}_{3}$ leaching in dry bean production has not been previously studied.

The overall objectives of this study were to compare several variables on dry bean $\mathrm{N}$ accumulation, $\mathrm{NO}_{3}$ leaching and residual inorganic soil $\mathrm{N}$, including: 1 ) deep tillage versus shallow tillage (breaking up the Bt horizon versus not), 2) PCU versus untreated $N$ sources at varying $\mathrm{N}$ rates and timing of application, and 3) interactions between tillage depth and $\mathrm{N}$ treatments.

\section{METHODS AND MATERIALS}

Field experiments were conducted over three years during 2005-2007 at the Central Lakes College Agricultural Irrigation Experiment Station near Staples, MN. The soil present at this location is a Verndale sandy loam (frigid Typic Argiudoll) with a $17 \mathrm{~cm}$ thick $\mathrm{Bt}$ horizon beginning at approximately $25 \mathrm{~cm}$ below the top of the soil. This area has a history of severe root rot and Estevez de Jensen et al. (2004) reported that the soil is naturally infested with Fusarium oxysporum, F. solani f. sp. phaseoli, and Rhizoctonia solani AG-4.

A detailed explanation of field practices and conditions for this study is reported in Wilson (2008). In summary, the previous crop in all three years was unfertilized, irrigated corn (Zea mays L.). Representative soil samples from 0-60 cm were collected in the spring before planting to determine $\mathrm{KCl}$ extractable nitrate- $\mathrm{N}\left(\mathrm{NO}_{3}-\mathrm{N}\right)$ and ammonium-N $\left(\mathrm{NH}_{4}-\mathrm{N}\right)$. Extractable soil $\mathrm{NO}_{3}-\mathrm{N}$ in the top $60 \mathrm{~cm}$ was $25.1,25.1$, and $6.3 \mathrm{~kg} \mathrm{ha}^{-1}$ in 2005, 2006, and 2007, respectively. Extractable soil $\mathrm{NH}_{4}-\mathrm{N}$ was $61.4,28.7$, and $73.5 \mathrm{~kg} \mathrm{ha}^{-1}$ in the consecutive years. Weather data were collected on station and thirty year precipitation and temperature normals for Staples, MN were obtained from the National Weather Service for comparison (MCWG, 2007).

A completely randomized block design with 6 replicates was used for all three years, with a split plot restriction on randomization. Two tillage 
treatments were replicated as whole plots: deep tillage (plowed to approximately $47 \mathrm{~cm}$ ) was intended to break up the Bt horizon, while conventional shallow tillage (plowed to approximately $29 \mathrm{~cm}$ ) was not. Subplots consisted of eight nitrogen $(\mathrm{N})$ treatments in 2005 and ten $\mathrm{N}$ treatments in 2006/2007 (Table 1). Subplots were four rows wide and $6 \mathrm{~m}$ in length with row spacing of $76 \mathrm{~cm}$. The non-inoculated dark red kidney bean cultivar "Montcalm" was sown on 31 May 2005, 24 May 2006 and 1 June 2007 to achieve an approximate density of $192 \times 10^{3}$ plants ha $^{-1}$.

Table 1. Nitrogen treatments applied to kidney beans (Phaseolus vulgaris $\mathrm{L}$ ).

\begin{tabular}{|c|c|c|c|c|c|}
\hline Treatment $^{1}$ & N Source & Planting & Emergence & $\begin{array}{l}\text { Prebloom } \\
\text { Sidedress }\end{array}$ & $\begin{array}{c}\text { Total N } \\
\text { Rate }\end{array}$ \\
\hline & & \multicolumn{4}{|c|}{ - } \\
\hline 1 & None & 0 & 0 & 0 & 0 \\
\hline 2 & WSPCU & 67 & 0 & 0 & 67 \\
\hline 3 & Urea & 67 & 0 & 0 & 67 \\
\hline 4 & PCU & 67 & 0 & 0 & 67 \\
\hline 5 & Urea & 0 & 34 & 0 & 34 \\
\hline 6 & PCU & 0 & 34 & 0 & 34 \\
\hline 7 & Urea & 0 & 34 & 35 & 67 \\
\hline 8 & PCU & 0 & 67 & 0 & 67 \\
\hline 9 & Urea & 0 & 34 & 67 & 101 \\
\hline 10 & PCU & 0 & 101 & 0 & 101 \\
\hline
\end{tabular}

${ }^{1}$ Treatments 2 and 3 were not included in 2005 study

Planter applied starter fertilizer was banded and consisted of $37 \mathrm{~kg} \mathrm{~K} \mathrm{ha}^{-1}$ and $17 \mathrm{~kg} \mathrm{~S} \mathrm{ha}^{-1}$ as $0-0$ 40-15. Two sources of $\mathrm{N}$, a 90-day release polymer coated urea (PCU) and an uncoated urea were compared across several rates and timing schemes in all three years. In 2006/2007 two additional treatments compared an additional $\mathrm{N}$ source, Nutrisphere Nitrogen (NSN; Specialty Fertilizer Products, Belton, MO) and urea to PCU at the same rate at planting. NSN is coated with a soluble polymer that is reported to reduce volatilization and nitrification (Balderson et al., 2007) and will be referred to as a water-soluble PCU (WSPCU). The three $\mathrm{N}$ sources applied at planting were banded $5 \mathrm{~cm}$ to the side and $5 \mathrm{~cm}$ below the seed. PCU and urea applied at emergence were broadcast by hand on 16 June, 8 June and 21 June in the three consecutive years. Urea applied at prebloom was sidedressed by hand on 29 June
2005, 28 June 2006, and 5 July 2007. Emergence and sidedress $\mathrm{N}$ applications were cultivated or irrigated into the soil within one day of application.

For measurement of soil-water $\mathrm{NO}_{3}$ concentration, suction cup samplers with a porous ceramic cup (1 bar high flow, Soil Moisture Equipment, Santa Barbara, CA) were installed $120 \mathrm{~cm}$ vertically below the soil surface in each plot according to methods described in Zvomuya et al. (2003). Samplers were installed within one week of planting in four replicates of each treatment. A suction of $40 \mathrm{kPa}$ was applied by hand pump to collect soil water draining through the soil at the depth of installation. A depth of $120 \mathrm{~cm}$ was assumed to be sufficiently below the root zone so that $\mathrm{NO}_{3}$ in the soil water was therefore leached. Soil water samples were collected approximately once a week during the growing season or more often if drainage was suspected to occur, such as after $1 \mathrm{~cm}$ or more of rain. Sampling began 2-3 weeks after planting and continued until ground freeze in November. Several samples were also taken after ground thaw during the following spring to determine residual soil-water $\mathrm{NO}_{3}$, although these were not used in leaching calculations. Samples were kept frozen until analysis and $\mathrm{NO}_{3}-\mathrm{N}$ was determined with a Hach DR4000 or DR50000 spectrophotometer (method 10049, Hach, 2005).

Soil moisture measurements were taken in tillage plots with a neutron probe (503DR Hydroprobe, Martinez, CA) in order to estimate stored soil water. One access tube made of galvanized steel electrical tubing was installed in the center of each tillage plot to an approximate depth of $2 \mathrm{~m}$ below the top of the soil within one week of planting. Soil moisture measurements were made for the top $120 \mathrm{~cm}$ in the soil, with readings taken every $24 \mathrm{~cm}$ beginning at $12 \mathrm{~cm}$ below the soil surface. Readings were taken once a week or more often if a drainage event was thought to have occurred. When evapotranspiration was low in the fall of each year, the soil water field capacity was determined for each tillage plot. For Verndale sandy loam, the average available water capacity 
is estimated to be $12.6 \mathrm{~cm}$ of water in the upper $120 \mathrm{~cm}$ of soil (Aldeen, 1991) but more precise measurements were needed. When antecedent moisture conditions (approximately $9 \mathrm{~cm}$ of water in $100 \mathrm{~cm}$ of soil) were relatively high preceding a significant rainfall event ( $>3.8 \mathrm{~cm}$ for this study), field capacity was assumed to have been exceeded. This allowed an estimation of field capacity after drainage occurred for at least 24 hours. For calibration purposes, soil samples were collected during installation of the access tubes and soil water content determined at depths corresponding to the depths at which neutron probe readings were taken in all years. Additionally, calibration equations were determined with methods similar to those in Douglass (1966). Three major horizons of soil (Ap, Bt and Bw horizons) at the study site were excavated, air dried and repacked into 200 liter drums. Measurements taken in dry soil and at saturation (after known amounts of water were added) and at several levels in between were related to soil wetness as determined by time domain reflectometry in order to calibrate the neutron probe for each specific soil horizon.

Daily water percolation at $120 \mathrm{~cm}$ below the dry bean crop was determined with the water balance equation as presented in Waddell et al. (2000) and field measurements of soil moisture. The water balance between two consecutive days was calculated as:

$$
\mathrm{D}=\mathrm{P}+\mathrm{I}-\mathrm{E}-\Delta \mathrm{S}
$$

where $D$ was the amount of daily drainage, $P$ was precipitation, $I$ was irrigation water applied, $E$ was evapotranspiration, and " $S$ was the change in soil water storage between two days. The $E$ values were calculated as a product of the potential evapotranspiration $\left(E_{\mathrm{o}}\right)$ estimated by a modified Jensen-Haise equation (Killen, 1984) and the crop coefficient $\left(K_{\mathrm{c}}\right)$ at a given crop developmental stage. The change in soil water storage was corrected by field measurements of soil moisture when measurements were available. Initial water storage at the beginning of the season and maximum water storage on any particular day was equal to the calculated soil water holding capacity of the $120 \mathrm{~cm}$ soil profile. Cumulative water percolation over the growing season was the sum of all percolation events from planting until 30 November of each year.

To determine the daily $\mathrm{NO}_{3}-\mathrm{N}$ leached, water percolation was converted to a volume basis, and multiplied by the $\mathrm{NO}_{3}-\mathrm{N}$ concentration of the soil water on that particular day. Since soil water samples were not taken on a daily basis, water $\mathrm{NO}_{3}-\mathrm{N}$ concentrations between two consecutive sampling dates were linearly interpolated for each day to cover the entire sampling period (June to November). The linear interpolation method may not account for daily fluctuations in $\mathrm{NO}_{3}-\mathrm{N}$ concentrations, but possible errors were minimized by sampling at short intervals and by maintaining a continuous vacuum in the suction samplers. Total $\mathrm{NO}_{3}$ leaching losses over the growing season were the sum of all daily leaching events during the sampling period.

Beans were harvested on 16 September 2005, 29 August 2006 and 7 September 2007. Plants were pulled by hand from the center $3 \mathrm{~m}$ of the center two rows in each plot and threshed in a combine to separate beans from plant material. Harvested dry beans were dried at $60^{\circ} \mathrm{C}$ until $0 \%$ moisture and then weighed for final yield. In addition, four plants from each plot were randomly selected for measurement of above ground dry matter and $\mathrm{N}$ accumulation. Plants were dried at $60^{\circ} \mathrm{C}$, and final weights for dry matter yield were obtained separately for beans and shoots. Beans were ground with a Stein Mill and shoots with a Wiley Mill to pass though a $2 \mathrm{~mm}$ screen. Total $\mathrm{N}$ in ground samples was determined with a combustion analyzer (Elementar Vario EL) following methods in Horneck and Miller (1998). Nitrogen content of shoots and beans was calculated as the product of dry matter yields and percent $\mathrm{N}$. Total $\mathrm{N}$ content was the sum of shoot and bean $\mathrm{N}$ contents.

After harvest, a composited five soil core sample to $60 \mathrm{~cm}$ depth was collected from each plot to 
determine the residual soil inorganic N. Soils were air dried, ground, and extracted with $2 \mathrm{M} \mathrm{KCl}$. Nitrate- $\mathrm{N}$ and $\mathrm{NH}_{4}-\mathrm{N}$ in $\mathrm{KCl}$ extracts were determined using the diffusion conductivity method (Carlson et al., 1990). Total inorganic $\mathrm{N}$ in the soil was the sum of soil $\mathrm{NO}_{3}-\mathrm{N}$ and $\mathrm{NH}_{4}-\mathrm{N}$.

Data from the study were analyzed with replicates as a random variable in PROC MIXED (SAS Institute Inc., 2004). The 2005 data were analyzed separately due to differences in $\mathrm{N}$ treatments from the other years. Data in 2006 and 2007 were combined and year was treated as a random effect. Treatment means were compared using leastsquare means and contrast statements (SAS Institute Inc., 2004). Fixed effects and mean separations with a p-value less than 0.10 were considered significant. As described by Littell et al. (2006), differences among treatments within years (the year by treatment interaction), were assessed by year-specific inference using best linear unbiased predictors (BLUPs). Pearson correlation coefficients in PROC CORR were used to test for correlations between variables (SAS Institute Inc., 2004).

\section{RESULTS AND DISCUSSION}

\section{Weather and Water Percolation}

The deviation of precipitation and temperature from the 30-year averages are in Table 2. Overall, all three years were warmer than on average, but 2005 was wetter and 2006 and 2007 were drier than normal conditions. Precipitation totals for the growing season (June - August) were 29.7, 18.2, and $9.6 \mathrm{~cm}$ for 2005, 2006, and 2007, respectively. Supplementary irrigation supplied an additional 11.7, 21.4 and $27.5 \mathrm{~cm}$ of water in consecutive years. Total water supply to the crop (precipitation + irrigation) was highest in 2005 and lowest in 2007.

Tillage treatments did not significantly affect cumulative water percolation, but there tended to be differences among years. Water percolation between planting and ground freeze was lower in 2006 than in 2007, and total percolation in 2005 and 2007 was similar (total percolation was 30.4, 21.3 and $30.3 \mathrm{~cm}$ in consecutive years). While 2005 and 2007 were comparable in total percolation, water movement over time is mainly influenced by rain patterns and irrigation, which varied greatly over years (Figure 1). In 2005, approximately $25 \%$ of the total water percolation occurred between planting and application of emergence fertilizer, while percolation remained relatively unchanged during the same time period in the following years (2007 had an initial leaching event at planting). Approximately 18, 11, and 11 $\mathrm{cm}$ of water had percolated from planting to harvest in 2005, 2006, and 2007, respectively. Considerable water losses occurred after harvest in all three years: $40 \%$ in 2005, 48\% in 2006, and $64 \%$ in 2007.

\section{Nitrate Leaching}

Nitrate leaching patterns over the growing season were greatly influenced by the rainfall patterns and irrigation of each year. In 2005, approximately $27 \%$ of total $\mathrm{NO}_{3}$ leached occurred between planting and emergence, while 38\% occurred after harvest (Figure 2). In 2006, only $2 \%$ of total leaching occurred between planting and emergence, while 43\% occurred after harvest (Figure 3). In 2007, 8\% of leaching occurred between planting and emergence while $68 \%$ of

Table 2. Departure of rainfall and temperature over three years from the 30 -year averages for Staples, MN.

\begin{tabular}{|c|c|c|c|c|c|c|c|c|}
\hline \multirow[b]{3}{*}{ Month } & \multicolumn{4}{|c|}{ Rainfall } & \multicolumn{4}{|c|}{ Temperature } \\
\hline & \multirow{2}{*}{$\begin{array}{c}\text { 30-Year } \\
\text { Mean }^{1}\end{array}$} & \multicolumn{3}{|c|}{ Departure from normal } & \multirow{2}{*}{$\begin{array}{c}\text { 30-Year } \\
\text { Mean }^{1}\end{array}$} & \multicolumn{3}{|c|}{ Departure from normal } \\
\hline & & 2005 & 2006 & 2007 & & 2005 & 2006 & 2007 \\
\hline May & 7.6 & 0.8 & -2.4 & 3.9 & 12.7 & -0.7 & 0.8 & 1.6 \\
\hline June & 10.8 & 3.3 & -4.4 & -6.2 & 17.4 & 2.0 & 1.0 & 2.0 \\
\hline July & 9.0 & -5.4 & -4.5 & -6.2 & 19.8 & 1.4 & 2.8 & 1.5 \\
\hline August & 8.0 & 3.9 & -0.8 & -6.0 & 18.8 & -0.2 & 0.7 & -0.3 \\
\hline september & 6.6 & 2.6 & 2.9 & 7.5 & 13.2 & 2.4 & -0.3 & 1.3 \\
\hline October & 6.6 & 0.2 & -2.1 & 3.6 & 6.5 & 1.5 & -1.3 & 2.2 \\
\hline November & 3.7 & 3.9 & -1.9 & -3.5 & -3.0 & 2.8 & 1.7 & 0.9 \\
\hline
\end{tabular}

${ }^{1}$ Average for the 30 year period from 1971-2000.

JEMREST 5:58-72, 2008 
total $\mathrm{NO}_{3}$ leaching occurred post-harvest (Figure 4). Differences between $\mathrm{N}$ sources generally began occurring between 15 and 45 days after planting (DAP) in 2005, at 70 DAP in 2006 and not until 108 DAP in 2007. High $\mathrm{NO}_{3}$ losses post-harvest were not only due to above average rainfall in all 3 years, but also because soil water $\mathrm{NO}_{3}$ concentrations slowly increased over the season to their peak levels after plant senescence and harvest (data not shown).

Figure 1. Daily precipitation and irrigation over three years during the growing season and the following fall months. Cumulative water percolation below $120 \mathrm{~cm}$ soil depth is also presented.

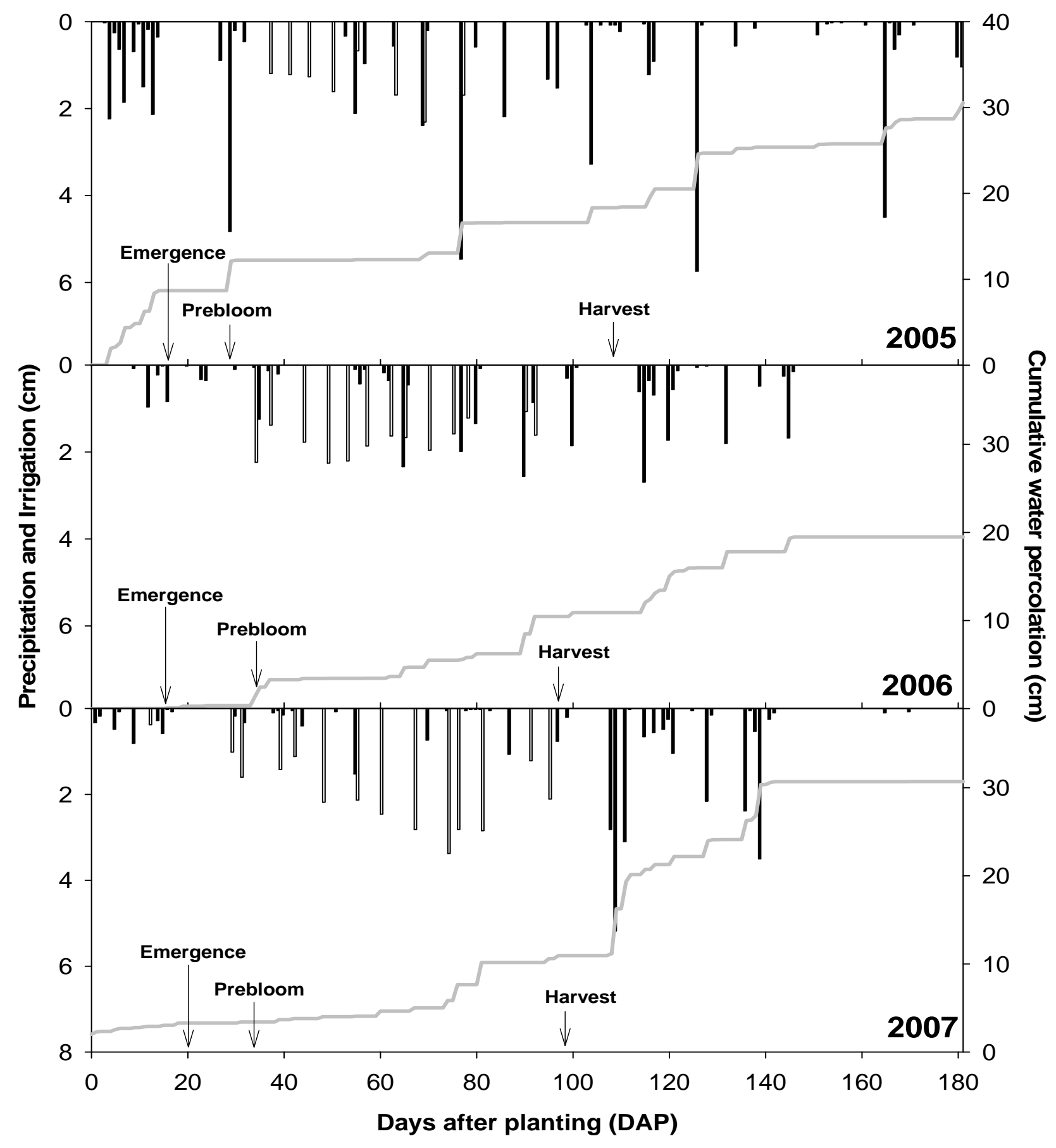

Precipitation $\square$ Irrigation $\longleftarrow$ Water percolation 
Figure 2. Daily and cumulative nitrate $\left(\mathrm{NO}_{3}\right)$ leaching over the 2005 growing season as influenced by $\mathbf{N}$ source, rate and timing. Emergence applications of $\mathbf{N}$ were either all applied at emergence. (PCU) or split applied at emergence and prebloom (urea).

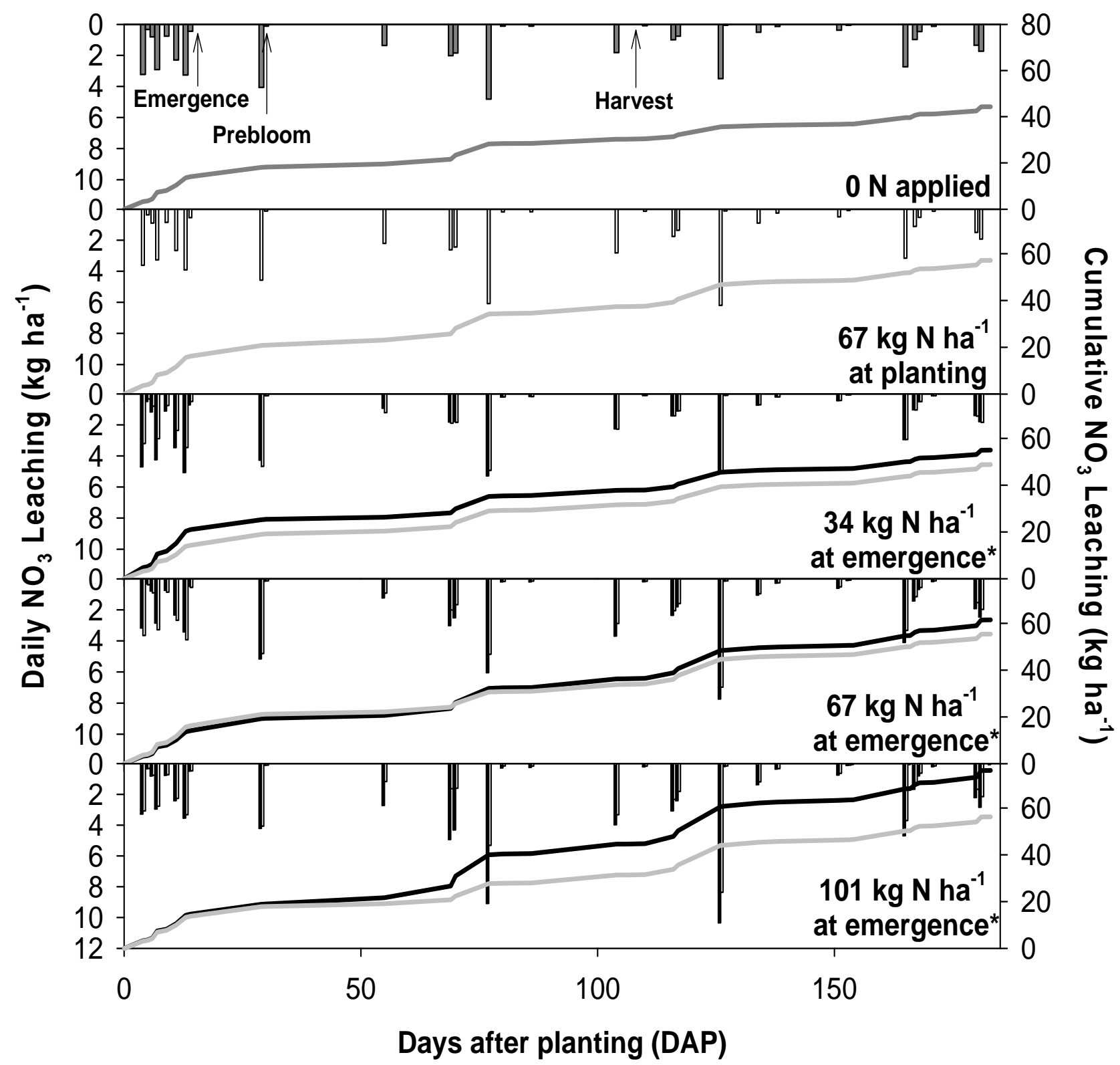

\section{Daily Leaching}

$0 \mathrm{~N}$ Control Urea $\square$ PCU

Cumulative Leaching

$0 \mathrm{~N}$ Control — Urea

PCU 
Figure 3. Daily and cumulative nitrate $\left(\mathrm{NO}_{3}\right)$ leaching over the 2006 growing season as influenced by $\mathbf{N}$ treatment, rate and timing. Emergence applications of $\mathbf{N}$ were either all applied at emergence(PCU) or split applied at emergence and prebloom (urea).

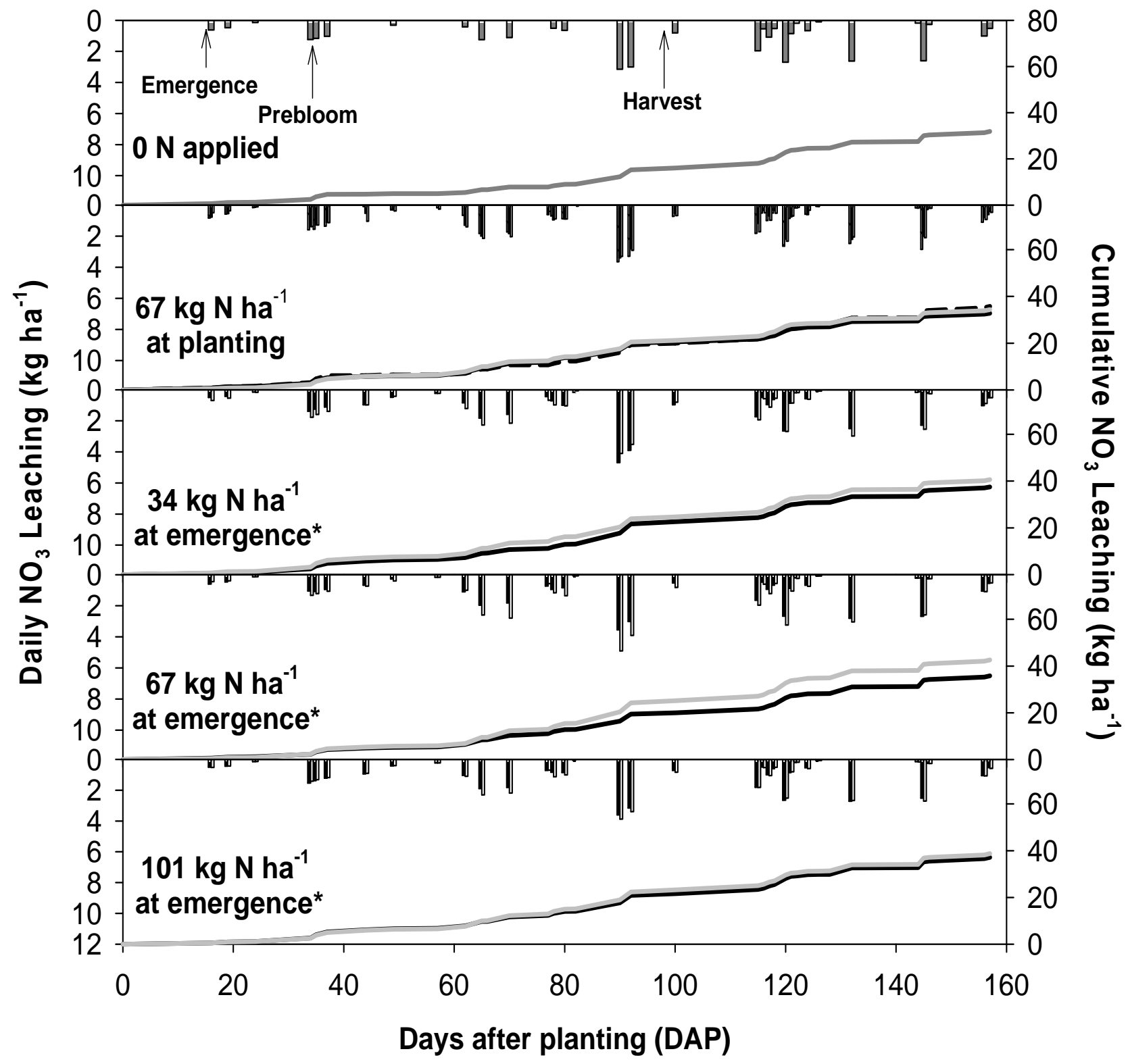

\section{Daily Leaching}

0 N Control $\square$ WSPCU $\square$ Urea $\square$ PCU

Cumulative Leaching

ON Control - - WSPCU - Urea $\longrightarrow$ PCU 
Figure 4. Daily and cumulative nitrate $\left(\mathrm{NO}_{3}\right)$ leaching over the 2007 growing season as influenced by $\mathbf{N}$ treatment, rate and timing. Emergence applications of $\mathbf{N}$ were either all applied at emergence (PCU) or split applied at emergence and prebloom (urea).

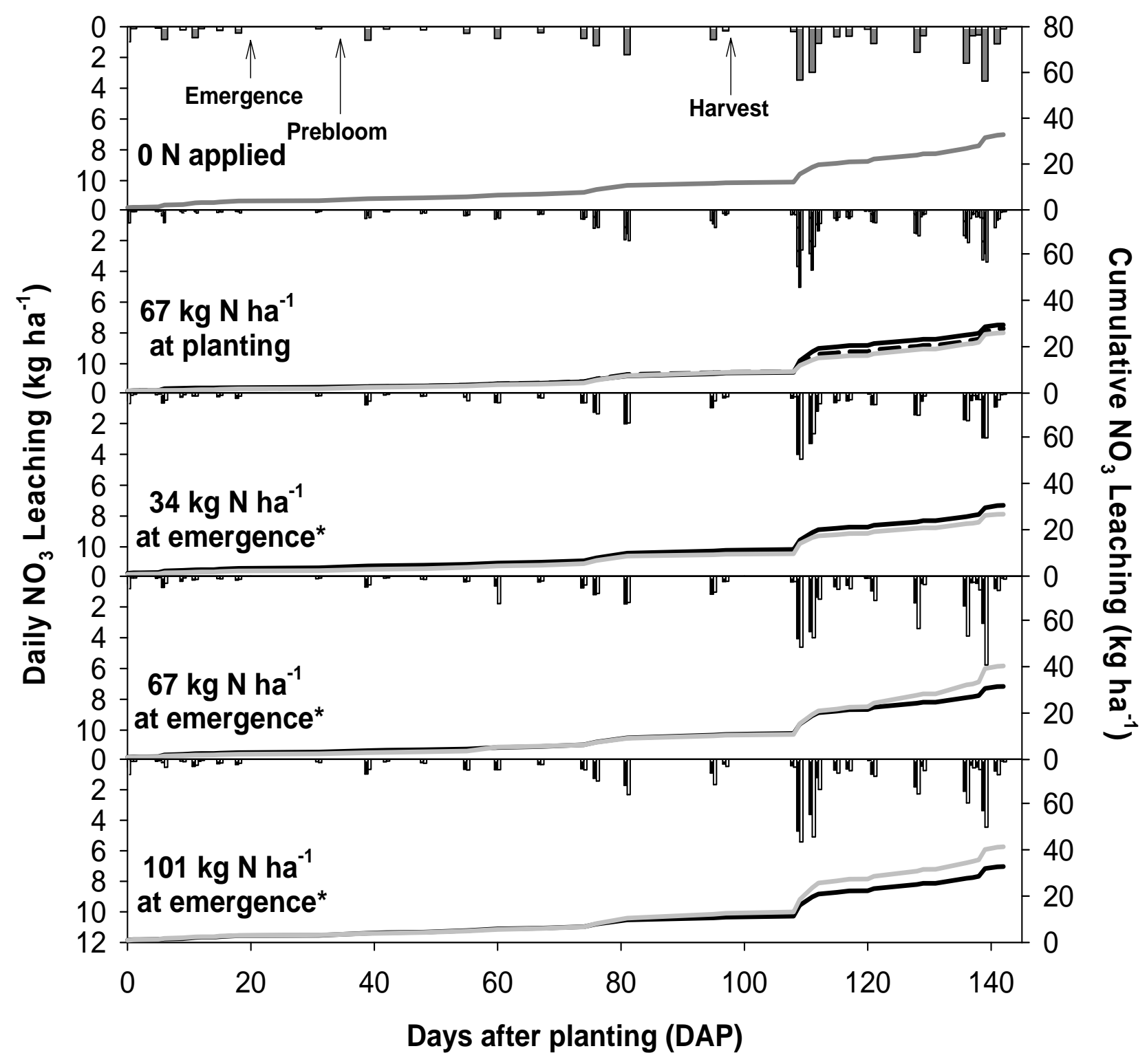

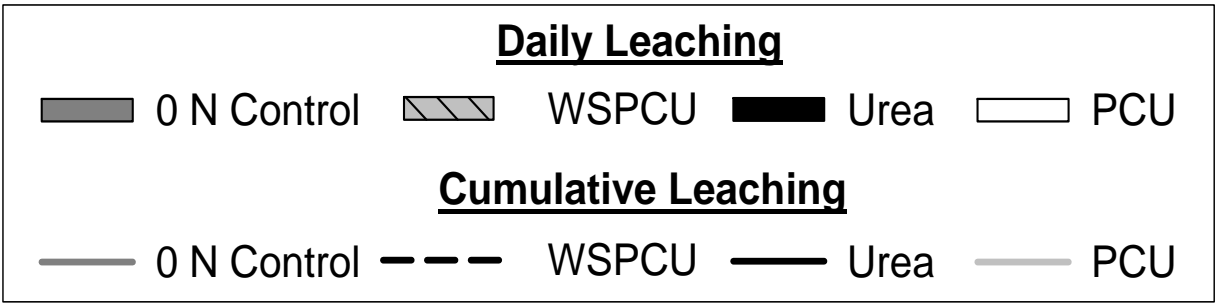


Meek et al. (1995) reported that approximately $42 \mathrm{~kg} \mathrm{~N} \mathrm{ha}^{-1}$ as $\mathrm{NO}_{3}$ leached from unfertilized dry beans in Idaho under normal precipitation conditions, which is similar to the $\mathrm{NO}_{3}$ leached from $0 \mathrm{~N}$ control in 2005. Cumulative $\mathrm{NO}_{3}$ leaching in 2006 and 2007 was generally lower due to low leaching conditions. In 2005, cumulative $\mathrm{NO}_{3}$ leaching was significantly affected by $\mathrm{N}$ treatments, but not by tillage or the tillage by $\mathrm{N}$ treatment interaction (Figure 5). In general, an increase in $\mathrm{N}$ rate caused numerical increases in $\mathrm{NO}_{3}$ leaching. However, only urea applied at $67 \mathrm{~kg} \mathrm{~N} \mathrm{ha}^{-1}$ and the highest rate of $\mathrm{N}$ (101 kg N ha-1) for both urea and PCU resulted in significantly higher $\mathrm{NO}_{3}$ leaching compared with the $0 \mathrm{~N}$ control. $\mathrm{N}$ source did not affect $\mathrm{NO}_{3}$ leaching at lower $\mathrm{N}$ rates, but $101 \mathrm{~kg} \mathrm{~N} \mathrm{ha}^{-1}$ of PCU resulted in significantly less nitrate leaching than urea at the equivalent rate. Contrast statements were used to compare all $\mathrm{N}$ rates of emergence PCU to all rates of split urea in 2005. $\mathrm{NO}_{3}$ leaching was significantly reduced with emergence PCU compared with split urea.

Figure 5. Cumulative nitrate $\left(\mathrm{NO}_{3}\right.$ ) leaching over the 2005 growing season and the following fall months (planting - 30 November). Bars with the same letter are not significantly different ( $p>0.10)$.

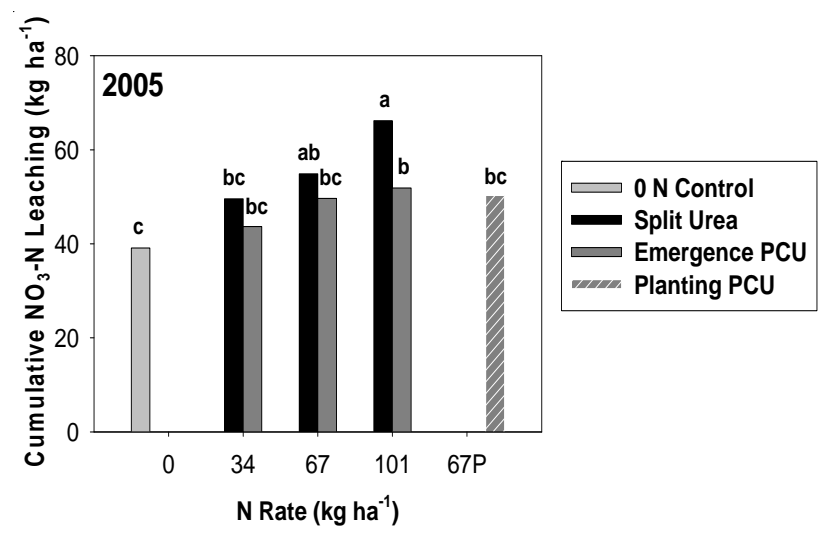

In the two year study over 2006 and 2007, tillage and $\mathrm{N}$ rate treatments did not significantly affect cumulative nitrate leaching most likely due to the low leaching conditions. Preplanned contrasts were used to further explore the data. All $\mathrm{N}$ rates of split urea and emergence PCU were compared and emergence PCU resulted in significantly more cumulative leaching than split urea. Planting PCU resulted in significantly less leaching than emergence PCU at the equivalent $\mathrm{N}$ rate, but it could not be compared to split urea. There were no significant differences between planting applied N sources.

The contrasting results in 2005 compared with $2006 / 2007$ are most likely due to differences in leaching conditions. In 2005, leaching occurred early in the season, when soluble urea is more prone to loss than PCU. In 2006 and 2007, N losses mainly occurred later in the season when soil water $\mathrm{NO}_{3}$ concentrations with emergence PCU were generally higher compared with split urea and planting PCU (data not shown). These results suggest that in years when leaching is high, emergence PCU can reduce $\mathrm{NO}_{3}$ leaching during the growing season, but it may increase leaching over split urea in years when high $\mathrm{N}$ losses occur after harvest. Winter cover crops have been shown to reduce $\mathrm{NO}_{3}$ leaching following harvest of vegetable crops (Wyland et al., 1996; BrandiDorhn et al., 1997) and may be necessary especially following PCU $\mathrm{N}$ applications.

Water sampling resumed the following spring after each experiment from ground thaw until the end of April. Averaged over experiments and $\mathrm{N}$ rates, soil water $\mathrm{NO}_{3}-\mathrm{N}$ concentrations were similar for emergence applied PCU (3 year mean $13.8 \pm 8.3$ $\mathrm{mg} \mathrm{L}^{-1}$ ), split applied urea (3 year mean $14.6 \pm$ $7.1 \mathrm{mg} \mathrm{L}^{-1}$ ) and the $0 \mathrm{~N}$ control (3 year mean 13.6 $\pm 7.6 \mathrm{mg} \mathrm{L}^{-1}$ ). Soil water $\mathrm{NO}_{3}-\mathrm{N}$ concentrations previously fertilized with planting applications of PCU and WSPCU in 2006 and 2007 (2 year means $14.4 \pm 4.9$ and $13.1 \pm 9.5 \mathrm{mg} \mathrm{L}^{-1}$, respectively) were generally higher than the $0 \mathrm{~N}$ control and planting applied urea (2 year means $9.7 \pm 4$.7 and $12.3 \pm 8.1 \mathrm{mg} \mathrm{L}^{-1}$, respectively). In $\mathrm{N}$ treated plots, mean soil water $\mathrm{NO}_{3}-\mathrm{N}$ concentrations were above the $10 \mathrm{mg} \mathrm{L}^{-1}$ limit, indicating the importance of a subsequent cover crop to reduce $\mathrm{NO}_{3}$ concentrations and potential leaching. 
Nitrogen Accumulation in Above Ground Plant Biomass

Nitrogen accumulation in the grain was more than half of the total $\mathrm{N}$ uptake in above ground plant biomass in all three years. During this time period, $\mathrm{N}$ accumulation in plant biomass (including plants in the $0 \mathrm{~N}$ control) was greater than $75 \mathrm{~kg} \mathrm{~N} \mathrm{ha}^{-1}$, suggesting that significant amounts of $\mathrm{N}$ were supplied by mineralization and $\mathrm{N}_{2}$ fixation. Tsai et al. (1993) reported that $\mathrm{N}_{2}$ fixation and mineralization supplied between $64-94 \%$ of total $\mathrm{N}$ in bean plants at varying soil fertility levels.

In 2005, mean separation tests showed similar results for all variables (shoot, grain and total $\mathrm{N}$ accumulation) so only total $\mathrm{N}$ uptake is discussed. Over the growing season, $\mathrm{N}$ treatments significantly affected total $\mathrm{N}$ uptake (Figure 6). The addition of $\mathrm{N}$ significantly increased $\mathrm{N}$ uptake in above ground plant biomass compared with the $0 \mathrm{~N}$ control. Although planting PCU resulted in the highest $\mathrm{N}$ accumulation, it was not significantly different from uptake with split urea at 67 and $101 \mathrm{~kg} \mathrm{~N} \mathrm{ha}^{-1}$. With urea applied at emergence and prebloom, $\mathrm{N}$ uptake increased as $\mathrm{N}$ rate increased to $67 \mathrm{~kg} \mathrm{~N} \mathrm{ha}^{-1}$ and then remained approximately the same at the highest rate. Nitrogen uptake did not significantly increase with increasing $\mathrm{N}$ rate for emergence PCU. Split urea applications generally resulted in more $\mathrm{N}$ accumulation than emergence PCU, but this difference was only significant at $67 \mathrm{~kg} \mathrm{~N} \mathrm{ha}^{-1}$. Split urea also resulted in significantly more $\mathrm{NO}_{3}$ leaching than emergence PCU. This trend suggests that split applications of urea may have increased $\mathrm{N}_{2}$ fixation over emergence PCU and therefore more soil water $\mathrm{NO}_{3}$ was available to plants or to be leached. Planting PCU, however, resulted in higher $\mathrm{N}$ accumulation than split urea at the same $\mathrm{N}$ rate, and lower $\mathrm{NO}_{3}$ leaching. While these differences were non-significant, the trend suggests that planting PCU may be more optimal for bean production compared with emergence PCU in leaching years.

In 2006 and 2007, N treatments significantly affected grain $\mathrm{N}$ content, but shoot $\mathrm{N}$ content was only affected by years. There was a significant $\mathrm{N}$ treatment by year interaction for total $\mathrm{N}$ uptake. Due to the methodology in PROC MIXED, mean separations tests cannot be performed on interactions that are specified as random, so best linear unbiased predictions (BLUPs) for treatments in each year along with their standard errors are provided in Figure 7. Using contrast statements as suggested in Littell et al. (2006), the interaction was found to be due to differences in emergence or later $\mathrm{N}$ applications. In 2006, total $\mathrm{N}$ uptake in split urea treatments was significantly higher than emergence PCU treatments, but in 2007, there was no difference between sources at equivalent $\mathrm{N}$ rates. There were no differences between $\mathrm{N}$ sources when applied at planting in either year.

Figure 6. Total nitrogen (N) uptake in 2005 in above ground plant biomass (shoots + grain). Stacked bars with the same letters are not significantly different $(p>0.10)$ and refer only to total $\mathrm{N}$ uptake.

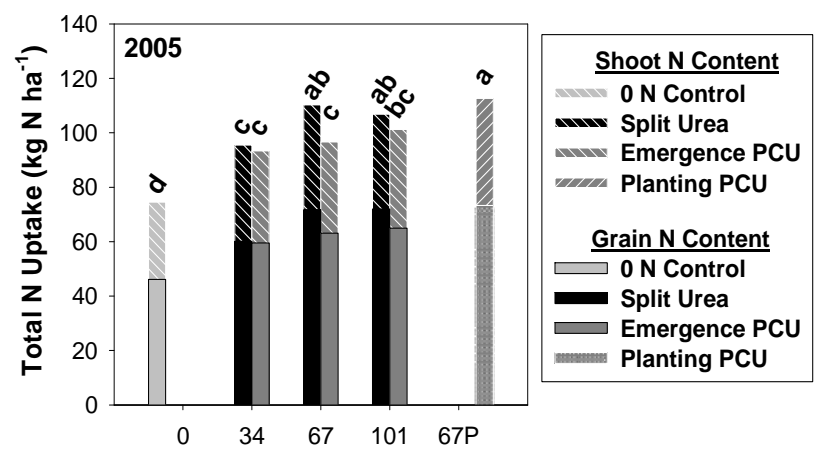

Average shoot $\mathrm{N}$ content in 2006 (43.9 kg N ha ${ }^{-1}$ ) was significantly higher than in 2007 (25.8 kg N ha $^{-1}$ ), but shoot $\mathrm{N}$ was not significantly affected by $\mathrm{N}$ treatments. The addition of $\mathrm{N}$ significantly increased $\mathrm{N}$ content in the grain over the zero $\mathrm{N}$ control, except the lowest $\mathrm{N}$ rate $\left(34 \mathrm{~kg} \mathrm{~N} \mathrm{ha}^{-1}\right)$ of emergence PCU (Figure 8). Grain N content was generally the highest with planting $\mathrm{N}$ applications, although grain $\mathrm{N}$ uptake with split urea and emergence PCU at $101 \mathrm{~kg} \mathrm{~N} \mathrm{ha}^{-1}$ and split urea at $67 \mathrm{~kg} \mathrm{~N} \mathrm{ha}^{-1}$ was not statistically different. Overall, planting WSPCU, PCU and urea resulted in similar grain $\mathrm{N}$ uptake. Based on a contrast 
statement comparing all split urea treatments to emergence PCU treatments, the split urea resulted in a significantly higher grain N content than emergence PCU.

Figure 7. The significant $\mathrm{N}$ treatment by year interaction for total nitrogen $(\mathrm{N})$ uptake in above ground plant biomass (shoots + grain).

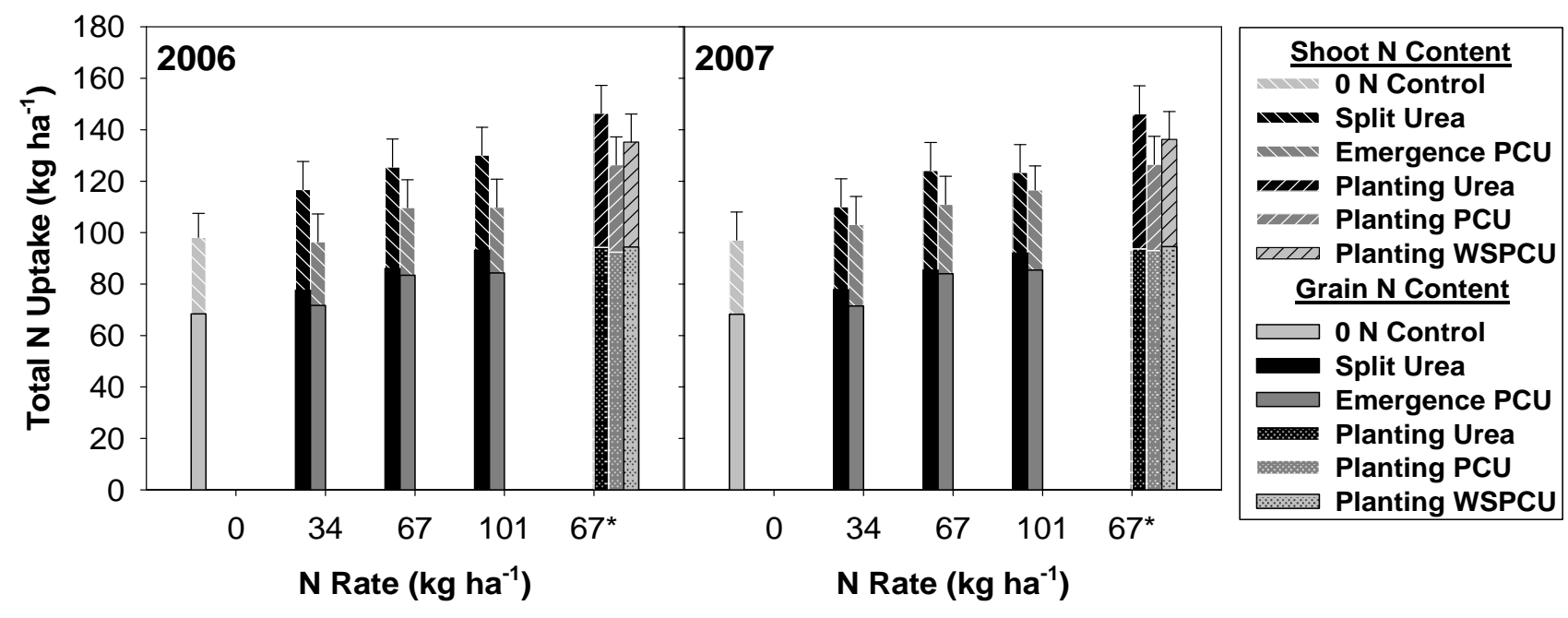

Figure 8. Grain nitrogen (N) content in 2006/ 2007 as affected by $\mathbf{N}$ source, rate and timing. Bars with the same letters are not significantly different ( $\mathbf{p}>\mathbf{0 . 1 0})$.

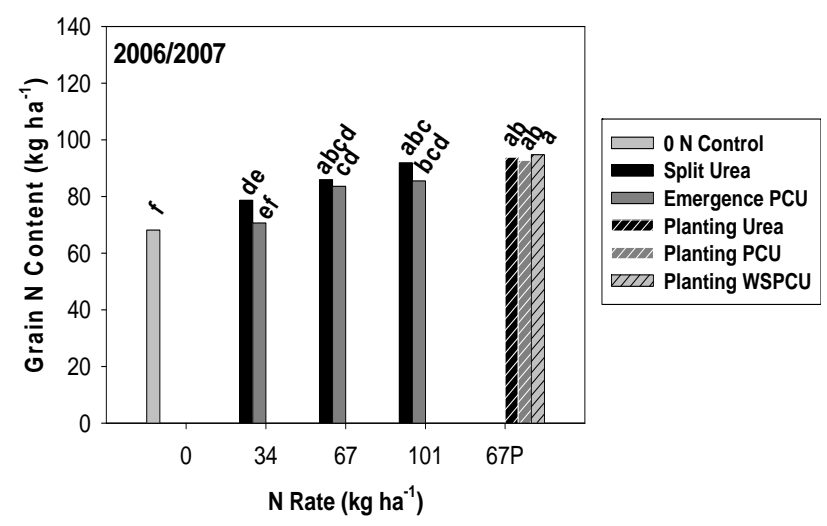

In two dry years, emergence PCU generally resulted in less $\mathrm{N}$ accumulation and more $\mathrm{NO}_{3}$ leaching compared with split urea, although differences were not always significant. Planting PCU, however, typically resulted in similar $\mathrm{N}$ accumulation and $\mathrm{NO}_{3}$ leaching to both planting and split applied urea. Combined with results from 2005, PCU at planting may be more optimal for

bean production compared with emergence applications regardless of leaching conditions during the growing season.

\section{Residual Soil Nitrate}

In 2005, the tillage by $\mathrm{N}$ treatment interaction was significant for total inorganic $\mathrm{N}$ in the soil (Figure 9). Soil $\mathrm{NO}_{3}-\mathrm{N}$, however, was not significantly affected by $\mathrm{N}$ treatment or tillage or the interaction between the two, so differences in total inorganic $\mathrm{N}$ were mainly controlled by differences in soil $\mathrm{NH}_{4}-\mathrm{N}$. With deep tillage, differences between emergence applied $\mathrm{N}$ sources were only found at the high $\mathrm{N}$ rate, while only the low rate resulted in significant differences in shallow tillage. In both cases, residual soil $\mathrm{N}$ was significantly higher with emergence PCU. Total soil N for planting applied PCU was similar to the $0 \mathrm{~N}$ control in both tillage treatments.

In 2006 and 2007, soil $\mathrm{NH}_{4}$ was approximately $66 \%-75 \%$ of total inorganic N. Large leaching events occurred between harvest and soil sampling and may have moved significant amounts of soil $\mathrm{NO}_{3}-\mathrm{N}$ past the $60 \mathrm{~cm}$ sampling depth. There were 
significant differences between years for total soil $\mathrm{N}$ and soil $\mathrm{NH}_{4}-\mathrm{N}$, but not soil $\mathrm{NO}_{3}-\mathrm{N}$. Total soil inorganic $\mathrm{N}$ was 72.9 and $140.9 \mathrm{~kg} \mathrm{~N} \mathrm{ha}^{-1}$ in 2006 and 2007, respectively, while soil $\mathrm{NH}_{4}-\mathrm{N}$ was 48.0 and $112.4 \mathrm{~kg} \mathrm{NH}_{4}-\mathrm{N} \mathrm{ha}^{-1}$ in consecutive years. Soil $\mathrm{NO}_{3}$-N averaged $26.9 \mathrm{~kg} \mathrm{NO}_{3}-\mathrm{N} \mathrm{ha}^{-1}$ in both years. Nitrogen treatments and tillage did not significantly affect residual soil inorganic $\mathrm{N}$ levels. Other studies that have reported much higher postharvest soil $\mathrm{NO}_{3}-\mathrm{N}$ levels compared with the present study. Kimura et al. (2004) reported 61-
$79 \mathrm{~kg} \mathrm{NO}_{3}-\mathrm{N} \mathrm{ha}^{-1}$ in the top $90 \mathrm{~cm}$ of a clay soil after harvest of unfertilized common bean. Meek et al. (1995) also studied unfertilized dry beans and reported 76 and $97 \mathrm{~kg} \mathrm{NO}_{3}-\mathrm{N} \mathrm{ha}^{-1}$ in the top 60 and $90 \mathrm{~cm}$ of a silt loam soil after harvest. Soil $\mathrm{NH}_{4}-\mathrm{N}$ was not presented in either study. In the current study, it is unclear as to why there was significantly more soil $\mathrm{NH}_{4}-\mathrm{N}$ in 2007 compared with 2006, but it is possible that there was more mineralization in 2007. Initial soil samples before planting also show higher soil $\mathrm{NH}_{4}-\mathrm{N}$ in 2007.

Figure 9. The interaction between tillage depth and $\mathbf{N}$ treatment on total soil inorganic $\mathbf{N}$ in the top $60 \mathrm{~cm}$ after harvest in 2005 . Stacked bars with the same letter (including both tillage depths) are not significantly different $(\mathbf{p}>\mathbf{0 . 1 0})$.

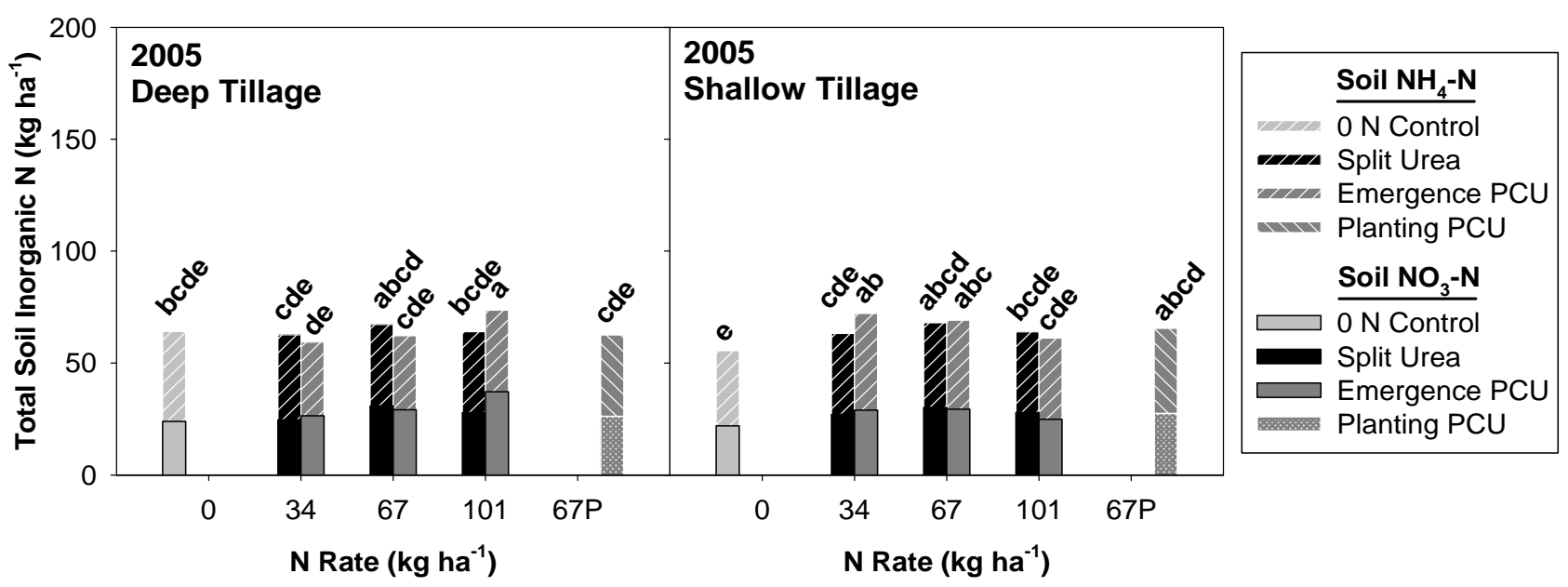

\section{CONCLUSIONS}

This study was conducted to examine the effects of tillage and a PCU on kidney bean production in Minnesota. Under the conditions of this study, tillage treatments did not significantly affect water percolation, plant $\mathrm{N}$ accumulation, nitrate leaching or the residual soil inorganic $\mathrm{N}$ except in combination with $\mathrm{N}$ treatments. During the study period, residual soil inorganic $\mathrm{N}$ was not affected by $\mathrm{N}$ source, but post-harvest soil $\mathrm{N}$ levels were relatively high and may require a cover crop to recover $\mathrm{N}$ to reduce $\mathrm{NO}_{3}$ leaching. In two dry years, WSPCU applied at planting resulted in similar grain $\mathrm{N}$ uptake and leaching as planting applied urea and PCU. Under the same conditions, PCU applied at emergence tended to result in lower grain $\mathrm{N}$ accumulation and more $\mathrm{NO}_{3}$ leaching compared with split applications of urea. In a wet year, however, emergence applied PCU significantly reduced $\mathrm{NO}_{3}$ leaching while plant $\mathrm{N}$ uptake was similar to split applied urea treatments. PCU applied at planting resulted in similar plant or grain $\mathrm{N}$ uptake as split applied and planting urea at equivalent $\mathrm{N}$ rates, and generally reduced $\mathrm{NO}_{3}$ leaching (although not always significant), regardless of leaching conditions. Combined with grain yield and monetary return data (Wilson, 2008), planting applied PCU has shown promising results for replacing soluble $\mathrm{N}$ sources to reduce $\mathrm{NO}_{3}$ leaching while maintaining yield. Further studies need to test the effect of WSPCU on grain 
yield and nitrate losses under leaching conditions.

\section{REFERENCES}

Aldeen, D.L. 1991. Soil survey of Wadena County, Minnesota. United States Department of Agriculture, Natural Resources Conservation Service, Washington, D.C.

Balderson, K., P. Davis, D. Moore, D. Johnson, G. Chappell, W. Lawrence, W. Alexander, C. Estienne, and W. Thomason. 2007. Virginia on-farm wheat test plots 2007. Virginia Coopertive Extension, Blacksburg, VA. Document 424-050.

Brandi-Dorhn, F.M., M. Hess, J.S. Selker, R.P. Dick, S.M. Kauffman, and D.D. Hemphill. 1997. Nitrate leaching under a cereal rye cover crop. J of Env. Qual. 26: 181-188.

Burke, D.W., D.E. Miller, L.D. Holmes, and A.W. Barker. 1972. Counteracting bean root rot by loosening the soil. Phytopathology 62: 306309.

Carlson, R.M., R.I. Cabrera, J.L. Paul, J. Quick, and R.Y. Evans. 1990. Rapid direct determination of ammonium and nitrate in soil and plant tissue extracts. Comm. in Soil Sci. and Plant Anal. 21: 1519-1529.

Douglass, J.E. 1966. Volumetric calibration of neutron moisture probes. Proc. Soil Sci. Soc. of Am. 30(5): 541-544.

Dou, H., and A.K. Alva. 1998. Nitrogen uptake and growth of two citrus rootstock seedlings in a sandy soil receiving different controlledrelease fertilizer sources. Bio. Fert.of Soils 26: 169-172.

Egel, D., R. Foster, E. Maynard, R. Weinzierl, M. Babadoost, H. Taber, R. Bauernfeind, T. Carey, M. Kennelly, B. Hutchinson, and B. Barrett (eds). 2008. Midwest vegetable production guide for commercial growers - 2008 .
University of Minnesota Extension Service, Saint Paul, MN. Document BU-07094.

Estevez de Jensen, E.C., J.E. Kurle, and J.A. Percich. 2004. Integrated management of edaphic and biotic factors limiting yield of irrigated soybean and dry bean in Minnesota. Field Crops Res. 86: 211-224.

[Hach] Hach Company. 2005. DR5000 spectrophotometer procedures manual. Edition 2. Catalog number DOC82.98.00670. Available from: <http://www.hach.com/ $\mathrm{f} \mathrm{m} \quad \mathrm{m} \quad \mathrm{i} \quad \mathrm{g} h \quad \mathrm{~h}$ c $\mathrm{h}$ ? / CODE\%3ADOC082.98.00670_1ED9088\%7C1>. Accessed 2008 April 17.

Harveson, R.M., J.A. Smith, and W.W. Stroup. 2005. Improving root health and yield of dry beans in the Nebraska Panhandle with a new technique for reducing soil compaction. Plant Disease 89(3): 279-284.

Horneck, D.A., and R.O. Miller. 1998. Determination of total nitrogen in plant tissue. In: Handbook of reference methods for plant analysis. Kalra, Y.P. (ed). CRC Press, Boston.

Killen, M.A. 1984. Modification of the checkbook method of irrigation scheduling for use in Minnesota MS thesis. University of Minnesota, Saint Paul, MN.

Kimura, S.D., K. Schmidtke, R. Tajima, K. Yoshida, N. Hiroshi, and R. Rauber. 2004. Seasonal $\mathrm{N}$ uptake and $\mathrm{N}_{2}$ fixation by common and adzuki bean at various spacings. Plant and Soil 258: 91-101.

Kipe-Nolt, J.A., and K.E. Giller. 1993. A field evaluation using the ${ }^{15} \mathrm{~N}$ isotope dilution method of lines of Phaseolus vulgaris L. bred for increased nitrogen fixation. Plant and Soil 152: 107-114.

Littell, R.C., G.A. Milliken, W.W. Stroup, R.D. Wolfinger, and O. Schabenberger. 2006. SAS 
for mixed models. Second Ed. SAS Institute Inc., Cary, NC.

[MCWG] Minnesota Climatology Working Group. 2007. Historical data retrieval: Closest station data retrieval. Saint Paul, MN. Available from: <http://climate.umn.edu/ hidradius/radius.asp> . Accessed 2008 Apr 9.

Meek, B.D., D.L. Carter, D.T. Westermann, J.L. Wright, and R.E. Peckenpaugh. 1995. Nitrate leaching under furrow irrigation as affected by crop sequence and tillage. Soil Sci. Soc.of Am. J. 59: 204-210.

[NASS] United States Department of Agriculture. National Agriculture Statistics Service. 2004. 2002 Census of Agriculture. United States Government Printing Office, Washington, D.C.

[NASS] United States Department of Agriculture. National Agriculture Statistics Service. 2007. Minnesota 2007 Agricultural Statistics. United States Government Printing Office, Washington, D.C.

Rennie, R.J., and G.A. Kemp. 1983. $\mathrm{N}_{2}$-fixation in field beans quantified by ${ }^{15} \mathrm{~N}$ isotope dilution. II. Effect of cultivars of beans. Agronomy J. 75: 645-649.

SAS Institute Inc. 2004. SAS/STAT ${ }^{\circledR} 9.1$ user's guide. SAS Institute Inc, Cary, NC.

Trenkel, M.E. 1997. Improving fertilizer use efficiency: Controlled-release and stabilized fertilizers in agriculture. International Fertilizer Industry Association, Paris, France.

Tsai, S.M., R. Bonetti, S.M. Agbala, and R. Rossetto. 1993. Minimizing the effect of mineral nitrogen on biological nitrogen fixation in common bean by increasing nutrient levels. Plant and Soil 152: 131-138.
Waddell, J.T., S.C. Gupta, J.F. Moncrief, C.J. Rosen, and D.D. Steele. 2000. Irrigation- and nitrogen-management impacts on nitrate leaching under potato. J. of Env. Qual. 29(1): 251-261.

Wilson, M.L. 2008. Crop productivity and nitrate leaching in coarse-textured soils as affected by the use of polymer coated urea and deep tillage. MS Thesis. University of Minnesota, Saint Paul, MN.

Wyland, L.J., L.E. Jackson, W.E. Chaney, K. Klonsky, S.T. Koike, and B. Kimple. 1996. Winter cover crops in a vegetable cropping system: Impacts on nitrate leaching, soil water, crop yield, pests and management costs. Ag., Ecosys. and Env. 59: 1-17.

Zvomuya, F., and C.J. Rosen. 2001. Evaluation of polyolefin-coated urea for potato production on a sandy soil. HortScience 36(6): 1057-1060.

Zvomuya, F., C.J. Rosen, M.P. Russelle, and S.C. Gupta. 2003. Nitrate leaching and nitrogen recovery following application of polyolefincoated urea to potato. J. of Env. Qual. 32:480489. 